\title{
Pituitary Adenylate Cyclase-Activating Polypeptide: A Promising Neuroprotective Peptide in Stroke
}

\author{
Yuanjian Fang ${ }^{1}$, Reng Ren ${ }^{1}$, Hui Shi ${ }^{2}$, Lei Huang ${ }^{3,4}$, Cameron Lenahan ${ }^{3,4,5}$, Qin Lu ${ }^{6}$, Lihui Tang ${ }^{1}$, \\ Yi Huang ${ }^{1}$, Jiping Tang ${ }^{3,4,7}$, Jianmin Zhang ${ }^{1 *}$, John H. Zhang ${ }^{3,4,7^{*}}$
}

${ }^{1}$ Department of Neurosurgery, The Second Affiliated Hospital, School of Medicine, Zhejiang University, Hangzhou, Zhejiang, China. ${ }^{2}$ Department of Neurosurgery, Yongchuan Hospital, Chongqing Medical University, Chongqing, China. ${ }^{3}$ Department of Neurosurgery, Loma Linda University, Loma Linda, CA, USA. ${ }^{4}$ Department of Physiology and Pharmacology, Loma Linda University, Loma Linda, CA, USA. ${ }^{5}$ Burrell College of Osteopathic Medicine, Las Cruces, NM, USA. ${ }^{6}$ Department of Neurosurgery, Sir Run Run Shaw Hospital, Zhejiang University, School of Medicine, Hangzhou, Zhejiang, China. ${ }^{7}$ Department of Anesthesiology, Loma Linda University, Loma Linda, CA, USA.

[Received June 2, 2020; Revised June 25, 2020; Accepted June 26, 2020]

\begin{abstract}
The search for viable, effective treatments for acute stroke continues to be a global priority due to the high mortality and morbidity. Current therapeutic treatments have limited effects, making the search for new treatments imperative. Pituitary adenylate cyclase-activating polypeptide (PACAP) is a well-established cytoprotective neuropeptide that participates in diverse neural physiological and pathological activities, such as neuronal proliferation, differentiation, and migration, as well as neuroprotection. It is considered a promising treatment in numerous neurological diseases. Thus, PACAP bears potential as a new therapeutic strategy for stroke treatment. Herein, we provide an overview pertaining to the current knowledge of PACAP, its receptors, and its potential neuroprotective role in the setting of stroke, as well as various mechanisms of neuroprotection involving ionic homeostasis, excitotoxicity, cell edema, oxidative stress, inflammation, and cell death, as well as the route of PACAP administration.
\end{abstract}

Key words: stroke, pituitary adenylate cyclase activating polypeptide, cerebral ischemia, intracerebral hemorrhage, subarachnoid hemorrhage

Stroke is a catastrophic disease associated with high mortality and morbidity in humans [1]. Stroke is traditionally divided into two subtypes: hemorrhagic stroke and ischemic stroke [2]. Despite the tremendous efforts emphasizing the prevention, treatment, and recovery of stroke, the mortality remains high [1]. Numerous pathophysiological mechanisms participate in brain injury following stroke, including excitotoxicity, ionic homeostatic disorder, oxidative stress, cell edema, cell death, and blood-brain barrier (BBB) dysfunction [3, 4]. Given the complexity of these processes, it is difficult to find potent drugs to treat stroke patients. Furthermore, the time required to progress from pre-clinical studies to clinical trials, and lastly, to clinical treatment, is extensive [5]. Despite these obstacles, stroke research is still encouraged, which may shed light on novel therapeutic treatments for stroke patients.

*Correspondence should be addressed to: Dr. John H. Zhang, Loma Linda University, Loma Linda, CA 92354, USA. Email: johnzhang3910@yahoo.com; Dr. Jianmin Zhang, Hangzhou, 310009, Zhejiang, China. Email: zjm135@zju.edu.cn

Copyright: $\odot 2020$ Fang Y et al. This is an open-access article distributed under the terms of the Creative Commons Attribution License, which permits unrestricted use, distribution, and reproduction in any medium, provided the original author and source are credited. 
Pituitary adenylate cyclase-activating polypeptide (PACAP) is a neuropeptide with a structure that has remained evolutionarily conserved since the protochordate. It was initially discovered in hypothalamic tissue three decades ago [6,7], and is considered as a member of the vasoactive intestinal peptide (VIP)/ glucagon/secretin family due to its high homology with VIP on the N-terminus amino acid sequence [7]. Until now, PACAP has been revealed to have widespread occurrence and diverse biological effects in mammalian peripheral and central nervous systems (CNS) [8, 9]. Accumulating evidence indicates that PACAP participates in neuronal proliferation, differentiation, and migration [10]. Recently, it was found to function as a potential effective therapeutic for various chronic nervous system disorders, such as post-traumatic stress disorder [11], multiple sclerosis [12], migraine [13], and even dry eye syndrome[14]. Furthermore, it was generally upregulated in several types of acute pathological conditions, including cerebral ischemia [15], intracerebral hemorrhage (ICH) [16], subarachnoid hemorrhage (SAH) [17], and traumatic brain injury [18]. Knockdown of PACAP or administration of exogenous PACAP in the animal model of ischemia stroke demonstrated the neuroprotection provided by PACAP, resulting in the attenuation of neurological deficits and pathological changes [19]. The clinical studies also indicated that the higher plasma PACAP level was significantly related to the improved prognosis of SAH and ICH patients $[16,17]$.

The aim of this review is to provide insight into the role of PACAP in stroke. Briefly, we first review the current knowledge of PACAP and its receptors within the nervous system. Then, we discuss the current known and potential neuroprotective mechanisms of PACAP against stroke in regard to ionic homeostatic, excitotoxicity, cell edema, oxidative stress, inflammation, cell death, and blood-brain barrier (BBB) dysfunction. Lastly, we summarize the various approaches of PACAP administration in the animal model of stroke.

\section{PACAP and receptors}

PACAP is a neuropeptide found in several brain regions of rodents (e.g. hypothalamus, anterior pituitary, hippocampus, superior colliculus [20], suprachiasmatic, paraventricular and periventricular hypothalamic nuclei [21], trigeminal nucleus caudalis, and cervical spinal cord [22]). Encoded by the ADCYAP1 gene located on chromosome 18, PACAP has two multiple transcript variants, PACAP27 and PACAP38, which are named according to the number of amino acids at the $\mathrm{N}$-terminus [23]. PACAP38 is considered the predominantly expressed isoform in mammalian tissues compared with PACAP27 [8].
As a member of the VIP/secretin/growth hormonereleasing hormone family, PACAP has a $68 \%$ sequence homology with VIP, and 37\% with secretin [24]. Due to the increased homology between PACAP and VIP, three different $G$ protein-coupled receptors are shared, which mediate the actions of VIP and PACAP, including PAC1 (encoded by Adcyap1r1, also named PAC1-R), VPAC1, and VPAC2 (encoded by Vipr1 and Vipr2, also known as VPAC1-R and VPAC2-R). Because PAC1 has a 100-fold selectivity for PACAP27 and PACAP38 over VIP, it functions as the primary receptor of PACAP [9]. In the rat brain, PAC1 is widely expressed in the cortex, hippocampus, olfactory bulb, brainstem, hypothalamus, and cerebellum $[25,26]$. While VPAC1 is mainly present in the cerebral cortex and hippocampus, VPAC2 is found primarily in the thalamus, hypothalamus, hippocampus, central nucleus of amygdala, and brainstem [27, 28].

Each PACAP receptor is coupled primarily to Gs or $\mathrm{Gq}$, which stimulate adenylyl cyclase (AC) and phospholipase $\mathrm{C}$ (PLC) activation. In the AC-involved signaling pathway, AC accelerates ATP conversion to cyclic adenosine monophosphate (cAMP), and then prompts protein kinase A (PKA) phosphorylation (primary) [29] and other cAMP downstream (secondary), such as exchange proteins activated by cAMP (EPAC) [30]. In contrast, PLC activation boosts both the protein kinase $\mathrm{C}$ (PKC) function [31, 32] and 1,4,5 inositol triphosphate (IP3) [33]. Furthermore, the PLC and AC/cAMP signaling pathway could mediate downstream targets, such as ras-associated protein-1 (RAP1)[34], MAPKs [35-38], NF-kB [39, 40], janus kinase (JAK) [41, 42], cJun [43, 44], and phosphatidylinositol 3-kinase (PI3K) [45]. In parallel with the PLC and AC/cAMP pathway, these downstream signaling pathways may also be directly activated by PAC 1 in some cells $[29,46,47]$ (Fig. 1).

\section{Function of PACAP in nervous system}

PACAP functions as a master regulator of the stress response, maintaining homeostasis within the central and peripheral nervous systems. In general, the functional roles of PACAP can be categorized as neuronal development, neuromodulation, and neuroprotection [10, 48].

PACAP participates in the development of neuronal and glial cells $[49,50]$. It mediates neuronal proliferation, migration, differentiation [51], and axonal growth and elongation [52]. As reviewed by Rivnyak et al. [10], these PACAP-involved processes are highly related to 1) several cell survival genes, such as the MAPK family (with downstream CREB) and calcium calmodulin pathway genes $[8,10]$; 2) cell cycle regulator family, cyclin and mitogenic related factors, such as janus kinase 
1 (JAK1) and the signal transducer and activator of transcription 3 (STAT3) [53, 54]; and 3) cell differentiation- and migration-related factors, including transforming growth factor beta (TGF- $\beta$ ), fibroblast growth factor (FGF21), nerve growth factor-induced protein A (EGR1), brain-derived neurotrophic factor (BDNF), insulin-like growth factor (IGF1), and bone morphogenic protein receptor type 2 [10]. Additionally, PACAP stimulates the myelination process by facilitating the proliferation of oligodendrocytes, while delaying their maturation [55]. Moreover, it promotes astrogliogenesis and differentiation only in non-carcinoma circumstances $[56,57]$.

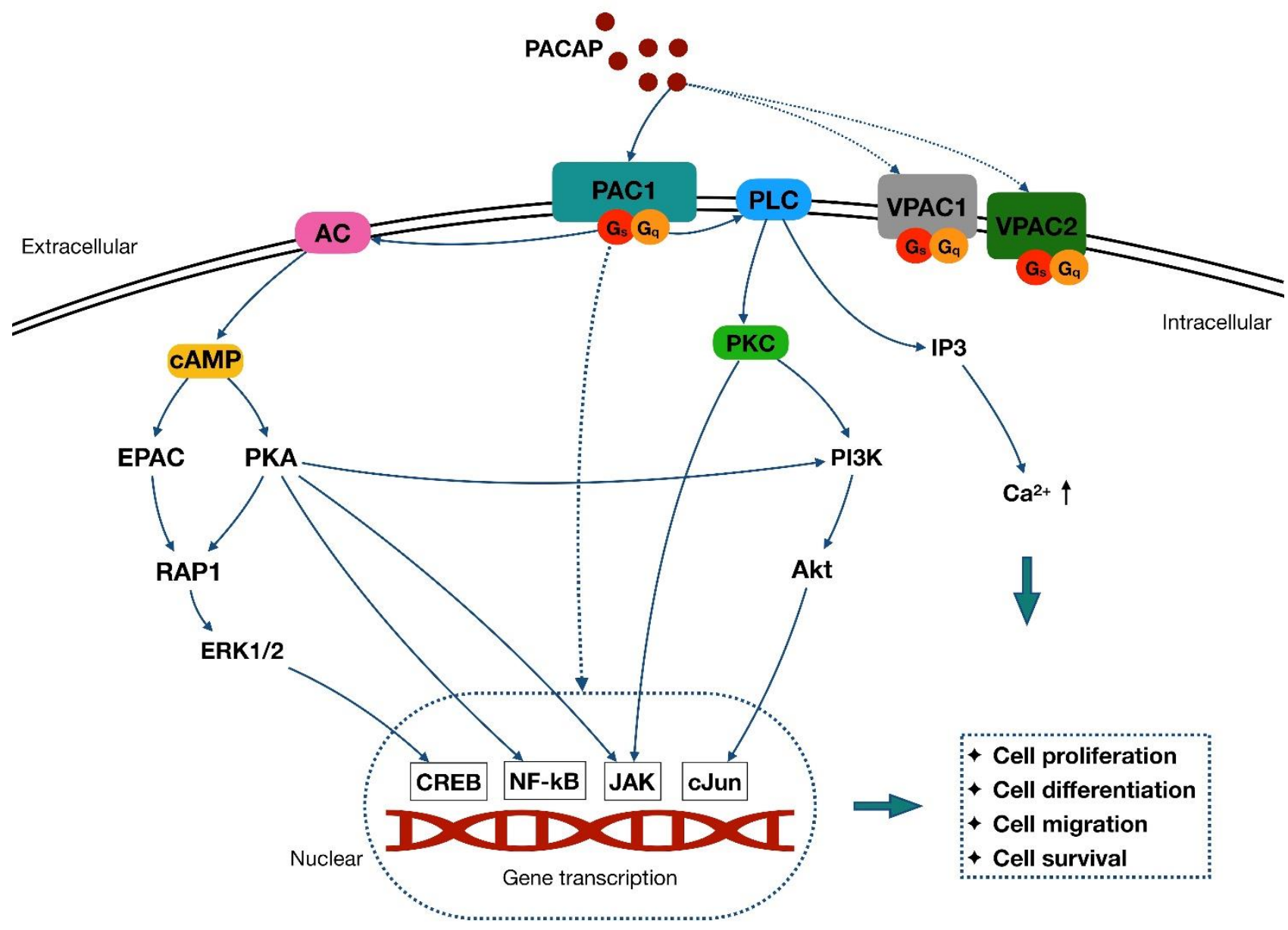

Figure 1. Schematic pathway of PACAP signaling cascades. PACAP exerts function via activation of three different G-protein coupled receptors: PAC1, VPAC1, and VPAC2. The PAC1 has a 100-fold selectivity for PACAP over VIP, contributing to its role as the main functional receptor of PACAP. Each PACAP receptor is coupled primarily to Gs or Gq, which stimulate AC and PLC activation. In the AC-involved signaling pathway, AC accelerates ATP conversion to cAMP, which then prompts PKA phosphorylation and activation of EPAC pathway. In contrast, activation of PLC boosts the PKC pathway, and the IP3 activation to increase the intracellular $\mathrm{Ca}^{2+}$. Both PLC and AC/cAMP signaling pathways are related to the PACAP function by mediating downstream targets, such as the MAPKs family and the PI3K/Akt pathway. These pathways further mediate cell proliferation, differentiation migration, and survival through several nuclear genes, such as CREB, NF-kB, JAK and cJun. Besides, these downstream signaling pathways also appear to be directly activated by PAC1 and are paralleled with PLC and AC/cAMP pathway in some cells.

PACAP is an important neurotransmitter and neuromodulator, functioning in behavioral processes, cognitive performance, emotional formation, and homeostatic regulation $[10,29,48]$. PACAP and the receptor, $\mathrm{PAC} 1$, are highly expressed in the hypothalamic nuclei, which is important for appetite and satiety $[58,59]$. Studies showed that PACAP administration negatively affected food intake in rodents $[60,61]$. This effect may be potentially integrated with the activity of the satietypromoting neuropeptides, proopiomelanocortin and $\alpha$ - 
melanocyte-stimulating hormone $(\alpha \mathrm{MSH})$, which are coexpressed with PACAP in the ventromedial, arcuate, and paraventricular nuclei of the hypothalamus [62, 63]. Similarly, PACAP is also co-expressed with leptin in the ventromedial nucleus, which then regulates thermogenesis and feeding [59]. The thermogenesis of PACAP is also regulated by brown adipose tissue, uncoupling protein 1 , and neurons within the sympathetic nervous system [64-66]. With the regulation of the sympathetic nervous system, PACAP is also involved in glycemic and lipocatabolic metabolism, which contributes to energy maintenance [66]. In terms of cognitive performance, PACAP participated in the hippocampal glutamatergic synaptic transmission, plasticity, and learning [67]. Accumulating evidence suggested that the reduced PACAP level was related to the development of cognitive impair in Alzheimer's disease, Parkinson's disease, and Huntington's disease [67].

PACAP is characterized as a sensory peptide, which further modulates emotional formation. It is expressed on the sensory dorsal root and trigeminal ganglion neurons, it participates in pain conduction and emotional formation $[68,69]$. Moreover, the role of PACAP in the peripheral pain circuits was widely acknowledged [70]. PACAP induces chronic pain by participating in pain signaling conduction, which is terminated in the lateral capsular division of the amygdala and limbic nucleus, further eliciting emotional responses, such as stress, anxiety, and fear [71, 72]. Based on these characteristics, PACAP is considered an important part of the pathogenic mechanism involved in post-traumatic stress disorder and migraines $[11,73]$.

Regarding neuroprotection, PACAP is engaged in endogenous protective mechanisms in the acute and chronic cell stress-response [10]. PACAP is generally upregulated in the CNS, and acts against neural damage from several harmful agents, such as kainic acid [74], ethanol, nicotine [75], oxidative stress-related agents [76], glucotoxicity, hypoglycemia-induced toxicity [77], betaamyloid peptide [78], and thrombin [79]. Administration of exogenous PACAP improved the outcomes in a variety of animal models, including traumatic brain injury[80], stroke [81], retinal ischemia [82], spinal cord injury [83], Parkinson's disease [84], Huntington's disease [85], and spinobulbar muscular atrophy [86].

\section{PACAP and PAC1 receptor changes after stroke}

PAC1 has been widely considered the main receptor of PACAP. Therefore, PACAP and PAC1 expression were often studied together in the setting of rodent stroke models. The brain levels of PACAP and PAC1 expression varied in the different regions and types of ischemic stroke [19]. Following global ischemia, PACAP was decreased in the first $24 \mathrm{~h}$, but increased 2-7 days after transient global ischemia in the murine hippocampus [87-89]. The upregulated PACAP may be secreted from neuronal stem cells in the subgranular zone, and from mature neurons in the hilus of the mice hippocampus [88]. Similarly, the PAC1 expression decreased in the hippocampus granule cells within the first 3 days after global ischemia [89], but increased 3-28 days after global ischemia in hippocampal astrocytes [90, 91]. These results indicated that the PACAP/PAC1 signaling pathway may play an important role in the hippocampal neurorepair process in the subacute and chronic stages after global ischemia. The protein kinase RNA-like endoplasmic reticulum kinase receptor response occurs within minutes to hours of unfolded protein response activation, which may account for the reduced PAC1 expression in the acute phase. This was shown to suppress PAC1 expression in the mouse neuroblastoma cell line [92].

Conversely, PACAP and PAC1 increased immediately in the cortex after focal cerebral ischemia induced by middle cerebral artery occlusion (MCAO) [93, 94]. PACAP and PAC1 were mainly expressed on cortical astrocytes, neurons, and endothelial cells [90, 93, 95]. The HIF-1 $\alpha$ activation after ischemia may increase the expression of PACAP signaling in the cortex. It promoted PACAP/PAC1 expression and homing of bone marrowderived cells to the hypoxic area. HIF-1 $\alpha$ is considered a double-sided transcription factor in different hypoxic conditions, which may explain the differences of PACAP and PAC1 expression that occur between global and focal ischemia [93].

Although ischemic conditions change region-specific crossing, exogenous PACAP treatment still exerted sufficient neuroprotection to the ischemic brain. A plethora of evidence has proven that exogenous PACAP reduces brain injury in both focal and global ischemia models [96-99]. However, the current research regarding the role of PACAP on hemorrhagic stroke is limited. Only two papers have indicated that the higher plasma PACAP level was related to a better outcome in SAH and ICH patients [16, 17]. Considering that there is plenty of overlap pertaining to the pathophysiological mechanisms of hemorrhagic and ischemic stroke, we boldly proposed that the PACAP treatments will attenuate both types of stroke by exerting the following neuroprotective effects: anti-apoptosis [43], anti-inflammation [46], anti-oxidative stress [100], anti-excitotoxicity [101], ionic equilibrium maintenance [102], and vascular protection [103] (Fig. 2). In the following sections, we will discuss how PACAP potentially regulates these molecular pathological processes in stroke. 


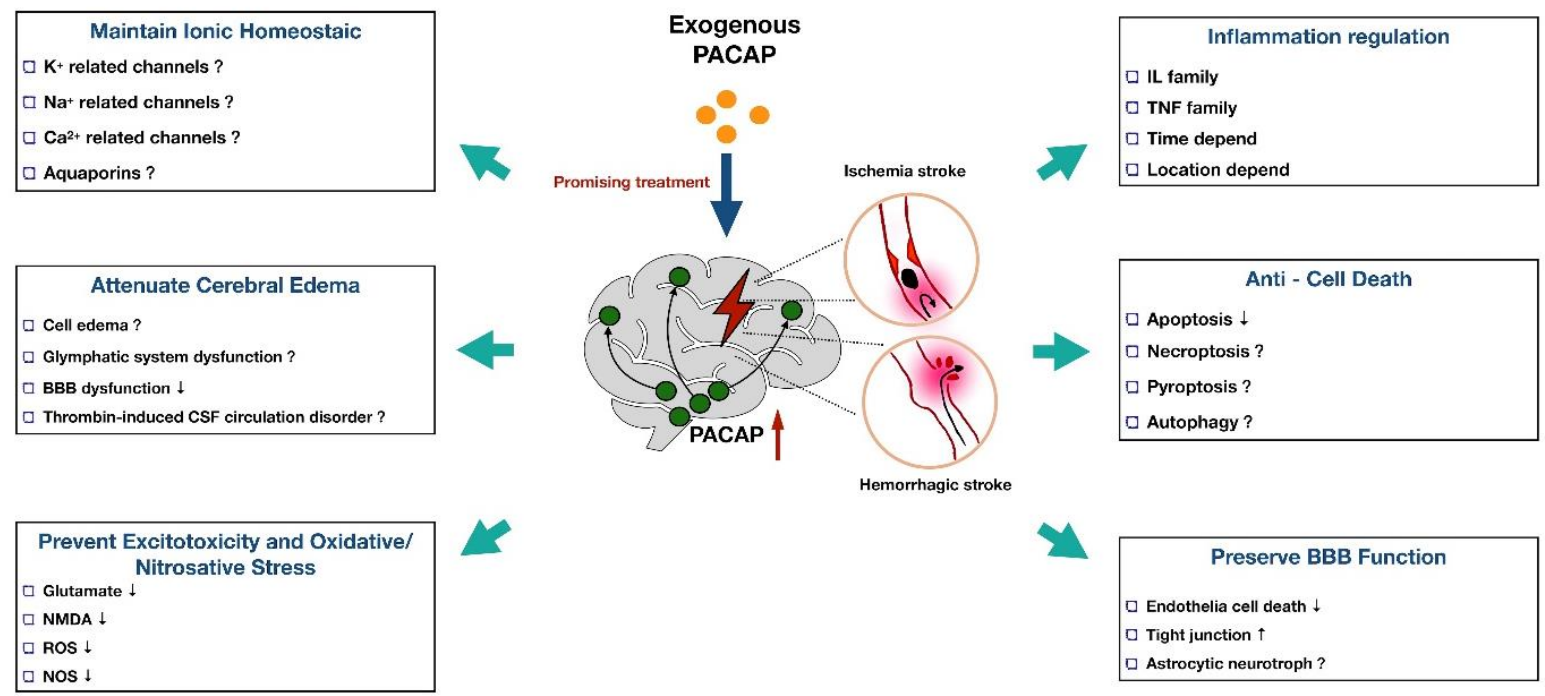

Figure 2. Current and proposed function of PACAP in different pathophysiology after stroke. PACAP is a promising neuroprotective peptide with great potential to mediate ionic homeostasis, cerebral edema formation, cytotoxicity, oxidative/nitrosative stress, inflammation, cell death, and BBB function after stroke.

\section{PACAP and potential mechanism of neuroprotection in stroke}

\section{PACAP and ionic homeostatic disorder}

Ion redistribution begins immediately after stroke and is associated with several pathological changes, including cell edema [104] and excitotoxicity [105]. Numerous ionic transporters, such as $\mathrm{Na}^{+}-\mathrm{K}^{+}$ATPase and $\mathrm{Ca}^{2+}$ ATPase, and ion channels and cotransporters, such as the $\mathrm{Na}^{+}-\mathrm{K}^{+}-\mathrm{Cl}^{-}$co-transporter $(\mathrm{NKCC} 1)$ and the $\mathrm{Na}^{+} / \mathrm{Ca}^{2+}$ exchanger, increases activity after stroke [104]. The influx of ions generates a transmembrane osmotic gradient that favors the influx of water and leads to cellular edema [106]. Dysfunction of calcium homeostatic machineries may exacerbate calcium overload and contribute to excitotoxicity companied with glutamate [107].

PACAP is a promising ionic homeostatic regulator. As reviewed, PACAP was involved in the modulation of several intrinsic ion or water channels responsible for mediating a variety of physiological activities, such as voltage-gated potassium channels [108], T-type calcium channels [109], voltage-gated sodium channels [110], and calcium-dependent potassium channels [30], which mediate neuronal excitability; hyperpolarizationactivated cyclic nucleotide gated channels, which mediate spike frequency and pacemaking in rhythmic firing neurons [111], and aquaporins (AQP), which mediate edema [112]. However, the effects of PACAP on these channels were completely regulated by different pathways. Phosphorylation via PKA, PKC, or ERK is considered a common mechanism of regulating channel activity [102]. In addition, PACAP could also increase intracellular calcium concentrations via activation of EPAC, which may promote calcium-dependent astrocytic differentiation of neural precursor cells [113].

In a study of a rat global cerebral ischemia model, it was found that the sodium contents increased, but the potassium contents decreased in the ischemic brain. Treatment with an intracerebroventricular injection of PACAP38 attenuated this ionic change in brain tissue [114]. Therefore, ion/water channels could be a potential therapeutic target of PACAP, which may mediate ion homeostatic disorder-induced cellular edema and excitotoxity in stroke.

\section{PACAP and cerebral edema}

Cerebral edema happens inevitably following stroke. It is initiated immediately after losing the cellular ionic redistribution, and largely depends upon the activity of ion/water channels or transporters on the neurovascular unit [115]. Changes in ion and water distribution generate abnormal osmotic forces that manifest as cerebral edema, further inducing or aggravating hypoxia, inflammation, cell death, and BBB disruption [104].

Exogenous PACAP38 treatment after ischemic stroke was proven to attenuate the increase in brain water content following transient global ischemia in rats via activation of PAC1 [114]. The brain edema volumes were also 
decreased in a mouse model of permanent MCAO (pMCAO) after exogenous PACAP38 treatment [116]. As for $\mathrm{SAH}$, we have found that PACAP38 treatment decreased the brain water content and intracerebral pressure increasement after SAH in rats (unpublished data).

It should be mentioned that PACAP is a controversial vasodilator, which mediates the dermal edema formation in mice and rabbits $[117,118]$. In a study focusing on the vasodilatory effect of PACAP, it was found that dosages higher than $50 \mathrm{nmol} / \mathrm{kg}$ (intravenous injection) would cause a long-lasting potent decline of arterial blood pressure, regional cerebral blood flow, and cerebral oxygen content in mice. Conversely, the low dosage would be safe for neuroprotective treatments of the brain [119]. However, there is no difference in changes of cerebral blood flow between the PACAP knockout and the PACAP wide-type mice during ischemia [116].

BBB disruption, glymphatic system dysfunction, and cerebrospinal fluid (CSF) circulation are mechanisms involved in edema formation $[104,120]$. After hemorrhagic stroke, thrombin and platelets are detrimental substances involved in the pathological change of the second brain injury that leads to cell death, inflammation, and CSF circulation blockage [121, 122]. Several studies have suggested that PACAP can inhibit the platelet aggregation induced by arachidonic acid and thrombin, potentially through the cAMP-dependent pathway [122]. In view of this, we postulate that the PACAP may attenuate brain edema by inhibiting thrombin- and platelet aggregation-induced impairment of CSF circulation after hemorrhagic stroke, which is worthy of further investigation in the future.

\section{PACAP and excitotoxic injury}

Excitotoxic injury is one of the major pathological changes after stroke, and is caused by an excess of excitatory amino acids, such as glutamate and N-MethylD-aspartate (NMDA) [105]. The over-accumulation of glutamate may result in a surge of calcium influx, causing high intracellular calcium concentrations, further leading to excitatory neuronal damage [123]. It was first found in several neuronal cell lines, such as the rat cortical neuronal cell line [124], PC12 cell line [125], and the rat motor neuron cell line [126]. Endogenous PACAP improved cell viability after excitotoxic glutamate exposure. The endogenous PACAP mRNA levels were upregulated after glutamate exposure in the rat neuron cell line [127]. The PAC1 receptor was suggested to be involved in the anti-excitotoxic process of PACAP. Treatment with PACAP6-38, the PAC1 selective antagonist, exacerbated cell death after glutamate exposure [127]. Meanwhile, PACAP was also shown to decrease glutamate-stimulated nitric oxide (NO) production in PC12 neurons, and further increased the cell viability. However, treatment with a PKA or PKC inhibitor abolished the downregulation of NO production. Moreover, the ERK inhibitor had no effect on this pathway [128].

NMDA also leads to excitotoxic injury after stroke. In the oxygen-glucose deprivation/reperfusion model of primary rat neural cells (40\% neurons and $60 \%$ astrocytes), PACAP attenuated cell death by modulating the expression levels of NMDA receptor subunits. PACAP increased the protein expression levels of the GluN1 subunit GluN2C (pro-survival), and decreased that of the GluN2B and GluN2D subunits (pro-cell death) [129]. Moreover, direct local treatment by non-vasoactive doses of PACAP (both PACAP27 and 38) prevented the post-ischemic cerebral vasodilation caused by NMDA in neonatal pigs [130].

Glutamate transporter-1 (GLT-1) is responsible for the majority of glutamate transportation to astrocytes, and plays an important role in preventing overstimulation of glutamate receptors [131]. The glutamate is further degraded by glutamine synthetase (GS) in astrocytes [132]. Exposure of cultured astroglia to PACAP-38 was found to be capable of upregulating the expression of GLT-1 and GS, which promoted the glutamate uptake via a PAC1-dependent manner. The PKA and PKC signaling was also involved in this pathway [132]. Additionally, PACAP-38 was proven to participate in the neuroprotection of Buyang Huanwu decoction (a Chinese herbal medicine). It conveys neuroprotection by upregulating the expression of GLT-1 and GS in the rat MCAO focal cerebral ischemia model [133]. Collectively, PACAP may exert neuroprotection through its potent anti-excitotoxicity effects after stroke. Additionally, in vivo studies are needed to validate the in vitro findings of PACAP, and to elucidate the potential downstream signaling pathways involved.

\section{PACAP and oxidative and nitrosative stress}

The oxidative and nitrosative stresses are characterized as an imbalance between the systemic manifestation of reactive oxygen/nitrogen species (ROS/RNS) and a biological system's ability to detoxify the ROS/RNS, which causes cell damage. In the sense, the oxidative and nitrosative stresses are downstream consequences of excitotoxicity. Excitotoxicity could result in a rise in secondary messenger systems, which would further trigger the enzymatic generation of free radicals, including cyclooxygenase and NOS after stroke [123, 134].

PACAP has been shown to attenuate oxidative stressinduced damage in several types of neural cells. In a 
neuronal culture, PACAP increases cell viability in cerebellar granule neurons that were exposed to $\mathrm{H}_{2} \mathrm{O}_{2}$ through a PAC1-, cAMP-, or MAPK-dependent pathway [76], and activated aconitase, a survival mitochondrial enzyme in response to oxidative stress [135]. PACAP also promotes the expression of several detoxifying kinases at the gene or protein level, such as peroxiredoxin 5, thioredoxin reductase [136], glutathione, and superoxide dismutase [137]. In glial cell culture, PACAP-38 reduces the production of microglia-derived ROS after $\mathrm{MPP}^{+}$ stimulation [138], suggesting that PACAP is also involved in microglia-mediated oxidative stress. PACAP38 activated PAC1, as well as the PKA, PKC, and MAPKs signaling pathways, which further inhibit the accumulation of ROS, and increases anti-oxidant enzymes, such as superoxide dismutase and catalase antioxidant enzyme in a cultured rat astrocytic cell line [138]. Moreover, PACAP also showed a pro-survival effect against glucose deprivation- and oxidative stressinduced junctional damage in the microvascular brain endothelial cell line [138]. The protective effects of PACAP have also been shown against lipopolysaccharide (LPS)-induced release of nitric oxide (NO) and lactate dehydrogenase [139], as well as NO-releasing neurotoxin sodium nitroprusside in primary cortical neuronal cultures [79].

Based on the current evidence regarding the prosurvival effects of PACAP in neural cells exposed to oxidative and nitrosative stress, the PACAP may be a promising anti-oxidative and anti-nitrosative treatment in animal models of stroke. However, limited studies have evaluated the effect of PACAP on oxidative and nitrosative stress after stroke in vivo. In a rat global ischemia model, PACAP-38 was proven to increase the hippocampal protein and mRNA level of 5 '-acting AP endonuclease 1 (APE1) activity and decrease DNA damage and neuronal death in the first day after reperfusion. The APE1, also known as redox-effector factor 1 , is a critical protein for base-excision repair after oxidative DNA damage[140]. The potential mechanism is that PACAP-38 upregulated PKA- and p38-dependent phosphorylation of CREB and activating transcription factor (ATF) 2, leading to transactivation of the APE1 promoter [141]. Nevertheless, future studies are necessary to validate the anti-oxidative mechanism of PACAP in animal models of stroke.

\section{PACAP and neuroinflammation}

The immune-mediated inflammatory response started immediately after the stimulation of several damageassociated molecular pattern molecules (DAMPs) produced by ischemia or hemorrhage [142, 143]. Inflammation plays a double-edged role in the pathogenesis of stroke and other forms of brain injury, as it not only exacerbates secondary brain injury in the acute stage of stroke, but also beneficially contributes to brain recovery after stroke [144]. It has been proven that PACAP is involved in a broad range of inflammatory responses, resulting in either anti-inflammatory or proinflammatory effects [145].

The current knowledge of PACAP on neural inflammation after stroke is mainly focused on the microglial and astrocytic response. The receptors of PAC1 and VPAC1 are expressed on both cultured astrocytes and microglia [146]. Pathological microglial activation is considered a pro-inflammatory source of neuronal damage after stroke, which initiates tumor necrosis factor (TNF)- $\alpha$, interleukin (IL)-1 $\beta$, IL-6, IL-12, and nitric oxide (NO) cascade in the brain [147]. Delgado et al. [148] first found that PACAP38 inhibited the inflammatory mediators in microglial cell cultures through a cAMP-dependent intracellular pathway, which also reduced p65 nuclear translocation and NF-kB DNA binding [148]. They also showed that this antiinflammatory effect of PACAP on activated microglia worked through inhibition of the MAPK cascades (MEKK1/MEK4/Jun N-terminal kinase (JNK)), which reduced the phosphorylation of c-Jun, and further inhibited the transcription of pro-inflammatory factors [149]. Moreover, another in vivo study showed that PACAP attenuates hypoxia-induced inflammatory activation of microglia by reducing $\mathrm{NO}$ and $\mathrm{TNF}-\alpha$, and protects co-cultured $\mathrm{PC} 12$ cells from microglial neurotoxicity through the MAPK p38 pathway [150]. However, it is notable that PACAP's effect on interleukin secretion in the microglia cell culture was contrary to the astrocyte cell line. PACAP significantly increased proinflammatory IL-6 levels in a rat primary astrocyte cell culture [151].

Overall, the MAPK family was involved in the inflammatory mediation of PACAP after stroke. In the rat global ischemia-reperfusion model, the MAPK family, including ERK, JNK, stress-activated protein kinase (SAPK), and P38 was increased from $3 \mathrm{~h}$ in the hippocampus after ischemia. The pre-intracerebroventricular injection of IL-6 inhibited the activation of JNK and ERK 24h after global ischemia, which proposed that the neuroprotection of IL-6 was exerted in the late phase after 24h [43]. It was also found that the PAC1 was upregulated along with IL-6 at only 3 to 7 days in hippocampal astrocytes rather than microglia after ischemia. In addition, pre-administration of low dosage PACAP38 (intracerebroventricular injection, 1pmol/ mice) could increase IL-6 [152] and further protect against neuronal apoptosis [43]. The neuroprotective effect of PACAP is also absent in IL-6 KO mice [81]. The evidence suggests that PACAP promotes the late phase of 
astrocytic neuroinflammation in the hippocampus. However, a recent study also showed that IL-6 was expressed in microglia and peri-infarct neurons in the first $24 \mathrm{~h}$ after focal ischemia, but the role of PACAP on IL-6 upregulation in the acute phase remains unclear [91].

The ischemic region-specific and time-dependent inflammatory response may potentially explain the divergence of PACAP effects in ischemic stroke. The effects of PACAP38 treatment on expression of cytokine genes, including IL-6, IL-22, IL1- $\beta$ and IL-11, varied between the ischemic core and penumbra at $24 \mathrm{~h}$ after pMCAO [153]. The PACAP suppressed IL-6 expression in the ischemic core and contralateral tissue, but prompted it in the ischemic penumbra, which partly suggested that the PACAP participates in neurodegeneration rather than neuroprotection in cerebral ischemia [153]. Moreover, a recent study proposed that delayed PACAP local delivery can prompt the microglial response toward a neuroprotective M2 phenotype in the late phase after ischemic stroke. The potential molecular mechanism involved the NF- $\kappa \mathrm{B}, \mathrm{CREB}$, and the Notch/RBP-J pathway [154].

Taken together, due to the complexity of the inflammatory response after ischemic stroke, future studies should combine both vivo and vitro experiments, and at different phases to further elucidate the role of PACAP on inflammation after ischemic stroke. Besides, more studies are required that emphasize the effects on hemorrhagic stroke. Lastly, PACAP regulates inflammation by mediating cytokine/chemokine production, neutrophil mobility/migration, and $\mathrm{T}$-cell differentiation in the peripheral nervous system [46, 145]. It regulates inflammation through widely expressed receptors in the immune cells. PAC1 is exclusively expressed on macrophages, while VPAC1 is expressed by all immune cells, such as macrophages, lymphocytes, and monocytes. Moreover, VPAC2 is expressed in lymphocytes and macrophages [145]. The local tissue and systemic stress response contribute to and mobilize the inflammatory response after stroke, respectively [123]. The effect of systemic administration of PACAP warrants further research in the future.

\section{PACAP and Cell death}

Cell death, considered a terminal point of many pathophysiological changes, contributes an important role of outcome after stroke [155]. The main cell death after stroke includes apoptosis and autophagy, as well as the programmed necrosis such as necroptosis and pyroptosis [155] . Apoptosis is widely studied as a downstream target of PACAP. Numerous studies showed that PACAP has a potent anti-apoptotic effect in ischemic stroke, both in vivo and vitro $[15,129,156,157]$. The involved mechanism may include the inhibition of the MAPK pathway, such as ERK, JNK/SAPK, and p38 signaling induced-apoptosis [44, 95]. The other classical downstream pathways of PACAP, cAMP/PKA, and $\mathrm{PI} 3 \mathrm{~K} / \mathrm{AKT}$ pathway were also involved in the antiapoptotic effect of PACAP in ischemic stroke [156, 157]. In addition to the direct activation of PAC1, PACAP also facilitated the neuroprotection of brain-derived neurotrophic factor (BDNF), which functions through the activation of tropomyosin-related kinase receptor type $\mathrm{B}$ (trkB) and neuronal growth inhibitory signaling molecules p75 (NTR) and Nogo receptor [156]. Furthermore, the tonic effect associated with astrocytes was also considered an anti-apoptotic mechanism of PACAP [15, 158].

Necroptosis and pyroptosis are two additional and important forms of programmed cell death after ischemia or hemorrhage in the brain. Both necroptosis and pyroptosis could be a result of inflammatory factors or DAMPs [4]. Recently, a paper revealed that PACAP is involved in the inhibition of necroptosis in atherosclerosis, and functions by mediating receptor interacting protein 3 (RIP3) expression, a key protein of necroptosis [159]. Additionally, PACAP can also inhibit several necroptosis and pyroptosis initiators, such as several inflammatory factors (IL family TNF family) and Toll-like receptors $[39,150]$. These findings suggest that PACAP may inhibit necroptosis and pyroptosis after stroke.

The role of autophagy remains controversial in the pathological change that occurs after stroke, which may be either pro-survival or pro-death to maintain cellular homeostasis [160]. The current opinion of the effect of PACAP on autophagy after stroke also remains unclear. However, it was shown that PACAP could attenuate autophagy-induced neuronal death after hypoxic stress administration through the MAPK/ERK pathway [161]. Besides, the anti-autophagic effect was also proposed in the studies of Alzheimer's disease [162] and atherosclerosis [159]. Interestingly, PACAP was shown to promote autophagy through the CREB pathway by preserving the acute hepatocyte death after ischemia reperfusion injury [163]. Based on the distinct roles of autophagy, we conclude that the effect of PACAP on autophagy after stroke is worthy of being further studied.

\section{$P A C A P$ and BBB dysfunction}

The $\mathrm{BBB}$ is an important system responsible for maintaining the cerebral microenvironment [164]. The function and structure of BBB would be damaged after stroke, further aggravating the pathological changes. The BBB consists of the neurovascular unit, including endothelial cells, astrocytes, pericytes, neurons, and 
microglia [4, 165]. Among them, endothelial cells and astrocytes function as the most important components of the BBB. While PACAP receptors are expressed both on endothelial cells and astrocytes [166, 167], the effects of PACAP on BBB after stroke remains unknown. In addition, few studies have described the role of PACAP in maintaining the functionality of the BBB. Several vitro studies showed the protective effect of PACAP on cerebral endothelial cells. The PACAP treatment improved the barrier properties of the brain endothelium by preserving the transendothelial electrical resistance (critical marker of tight junction) after glucose deprivation and oxidative stress insults. However, it failed to prevent the apoptosis of endothelial cells [166]. In another study, the PACAP level was found to be markedly decreased in the aged endothelial cells compared with the young endothelial cell. Similarly, the PACAP treatment protected endothelial cells by promoting endothelial tube formation, and by reducing apoptosis and ROS production [168]. Further studies are needed to extend the research regarding the effect of PACAP on the neurovascular unit (not only endothelial cells but astrocytes) of BBB after stroke.

Table 1. The approaches of PACAP38 administration in stroke.

\begin{tabular}{|c|c|c|c|c|c|c|c|}
\hline \multirow{2}{*}{ Year } & \multirow{2}{*}{ Author } & \multirow{2}{*}{ Animal } & \multirow{2}{*}{ Model } & \multicolumn{4}{|c|}{ Administration } \\
\hline & & & & Routes & Starting time & Duration & Best dosage \\
\hline 1996 & Uchida D. et.al.[15] & Rats & $\begin{array}{l}\text { Transient global } \\
\text { ischemia }\end{array}$ & $\begin{array}{l}\text { i.c.v. } \\
\text { i.v. }\end{array}$ & $\begin{array}{l}\text { Post-surgery } \\
\text { Post-surgery } \\
\text { and post- } 24 \mathrm{~h}\end{array}$ & Continuous & $\begin{array}{l}1 \mathrm{pmol} / \mathrm{h} \\
16 \mathrm{pmol} / \mathrm{h} \text { and } \\
160 \mathrm{pmol} / \mathrm{h}\end{array}$ \\
\hline 1998 & $\begin{array}{l}\text { Somogyvari-vigh A. } \\
\text { et.al.[172] }\end{array}$ & Rats & $\begin{array}{l}\text { Transient global } \\
\text { ischemia }\end{array}$ & i.v. & Post-24h & $\begin{array}{l}\text { Single with } \\
\text { continuous }\end{array}$ & $\begin{array}{l}5 \mathrm{nmol} / \mathrm{kg} \text { with } \\
160 \mathrm{pmol} / \mathrm{h}\end{array}$ \\
\hline 1998 & Shioda F. et.al.[43] & Rats & $\begin{array}{l}\text { Transient global } \\
\text { ischemia }\end{array}$ & i.c.v. & Pre- $48 \mathrm{~h}$ & Continuous & $1 \mathrm{pmol} / \mathrm{h}$ \\
\hline 2000 & Reglodi D. et.al.[98] & Rats & tMCAO & i.v. & Post-6h & $\begin{array}{l}\text { Single with } \\
\text { continuous }\end{array}$ & $\begin{array}{l}20 \mathrm{nmol} / \mathrm{kg} \\
\text { with } \\
160 \mathrm{pmol} / \mathrm{h}\end{array}$ \\
\hline 2000 & Reglodi D. et.al.[99] & Rats & tMCAO & i.v. & $\begin{array}{l}\text { Post- } 4 \mathrm{~h}, 8 \mathrm{~h}, \\
12 \mathrm{~h}\end{array}$ & $\begin{array}{l}\text { Single with } \\
\text { continuous }\end{array}$ & $\begin{array}{l}5 \mathrm{nmol} / \mathrm{rat} \text { with } \\
160 \mathrm{pmol} / \mathrm{h}\end{array}$ \\
\hline 2002 & Dohi K. et.al.[44] & Rats & $\mathrm{tMCAO}$ & i.c.v. & Pre- $48 \mathrm{~h}$ & Continuous & $1 \mathrm{pmol} / \mathrm{h}$ \\
\hline 2002 & Yan D. et.al.[114] & Rats & $\begin{array}{l}\text { Transient global } \\
\text { ischemia }\end{array}$ & i.c.v. & Pre-15min & Single & $10 \mathrm{nmol} / \mathrm{rat}$ \\
\hline 2002 & Tamas A. et.al.[96] & Rats & pMCAO & i.c.v. & Pre-surgery & Single & 450pmol/rat \\
\hline $\begin{array}{l}2002 \& 20 \\
04\end{array}$ & Reglodi D. et.al.[157, 171] & Rats & pMCAO & i.c.v. & Pre-surgery & Single & $2 \mu \mathrm{g} / \mathrm{rat}$ \\
\hline 2006 & Chen Y. et.al.[97] & Mice & pMCAO & $\begin{array}{l}\text { i.c.v. } \\
\text { i.v. }\end{array}$ & Post-1h & Single & $\begin{array}{l}40 \mathrm{pmol} / \mathrm{mous} \\
\mathrm{e} \\
0.75 \mathrm{nmol} / \mathrm{mou} \\
\mathrm{se}\end{array}$ \\
\hline 2009 & Lenti L. et.al.[130] & $\begin{array}{l}\text { Newborn } \\
\text { pigs }\end{array}$ & $\begin{array}{l}\mathrm{CO} 2 \text { ventilation } \\
\text { induced transient } \\
\text { global ischemia }\end{array}$ & $\begin{array}{l}\text { Directiv } \\
\mathrm{e} \\
\text { expose }\end{array}$ & $\begin{array}{l}\text { Pre-CO2 } \\
\text { ventilation }\end{array}$ & Continuous & 10pmol/L \\
\hline 2010 & Stetler RA. et.al.[141] & Rats & $\begin{array}{l}\text { Transient global } \\
\text { ischemia }\end{array}$ & i.c.v. & $\begin{array}{l}\text { Pre-24, 12, } \\
6 \mathrm{~h}\end{array}$ & Single & 200pmol/rat \\
\hline 2012 & Lazarovici P. et.al,[156] & Rats & $\mathrm{tMCAO}$ & i.v. & Post-2h & Single & $30 \mathrm{ng} / \mathrm{kg}$ \\
\hline 2012 & Nakamachi T. et.al.[152] & Mice & $\begin{array}{l}\text { Transient global } \\
\text { ischemia }\end{array}$ & i.c.v. & Post-surgery & Single & $1 \mathrm{pmol} / \mathrm{mice}$ \\
\hline 2014 & Hori M. et. al.[153] & Mice & pMCAO & i.c.v. & Post-surgery & Single & $1 \mathrm{pmol} / \mathrm{mice}$ \\
\hline 2014 & Lin C. et al.[93] & Rats & $\begin{array}{l}\text { Transient global } \\
\text { ischemia }\end{array}$ & i.p. & Post- $4 \mathrm{~h}$ & Single & $10 \mu \mathrm{g} / \mathrm{kg}$ \\
\hline 2015 & Brifault C. et.al.[154] & Mice & pMCAO & i.c.v. & Post-72h & Single & $\begin{array}{l}\text { PACAP- } \\
\text { producing- } \\
\text { stem cell }\end{array}$ \\
\hline
\end{tabular}

\section{Routes of PACAP administration in stroke}

Based on current animal studies, a total of four PACAP administration routes were used in stroke, including intracerebroventricular, intravenous, intraperitoneal, and direct exposure [169] (Table 1).
In spite of the evidence that PACAP can easily pass the $\mathrm{BBB}$ [170], intracerebroventricular administration is still considered a relatively more effective way to reach drug function in the brain. Both pre- and post-ischemia intracerebroventricular PACAP38 treatment have been proven to attenuate the global and focal ischemia-induced brain damage $[43,44,114,141,152,157,171]$. Both 
continuous infusion and single injection was used in preor post-ischemia treatment. Pre-ischemia continuous infusion was usually started $48 \mathrm{~h}$ before ischemia with a small dosage and rate $(1 \mathrm{pmol} / \mathrm{L})[43,44]$, which allowed the full distribution of PACAP38 within the brain and CSF. A pre-ischemia single injection was regularly performed a few minutes before ischemia. However, the dosage ranged from $0.2-10 \mathrm{nmol}$ per rat in different studies $[96,114,141]$. For the post-ischemia treatment, PACAP38 was generally injected immediately after ischemia with a small dosage of 1 pmol per mouse [152, 153]. Continuous infusion with $1 \mathrm{pmol} / \mathrm{L}$ for rats and a single injection with 40 pmol per mouse were also proven to be neuroprotective. Recently, a novel approach demonstrated that delayed PACAP38 delivery by PACAP-producing stem cells can also promote infarct zone repair [154], which broadens the time window of intracerebroventricular PACAP38 treatment.

As a systemic peptide, intravenous injection of PACAP may have great importance, not only because of its capacity to pass the $\mathrm{BBB}$, but also because of its capability of suppressing the systemic inflammatory response [153]. Intravenous injection was regularly used after ischemia with both single bolus injection and continuous infusion, which avoided the problem of PACAP degrading rapidly within the systemic circulation [172]. The single bolus injection dosage ranged from 5-20 $\mathrm{nmol} / \mathrm{kg}$, and the continuous infusion rate ranged from 16$160 \mathrm{pmol} / \mathrm{h}$ in rats $[15,98,99]$. Interestingly, the single injection with $30 \mathrm{ng} / \mathrm{kg}$ PACAP38 was proven to function as a neuroprotective agent in the rat focal ischemia model [156]. The intraperitoneal single injection after ischemia was also shown to be effective in delivering PACAP38 to the brain, and further attenuated the ischemia [93].

In addition, it should be mentioned that although the intranasal administration has not been used for investigating the therapeutic value of PACAP on stroke, the intranasal administration is still a recommended method for PACAP delivery. Intranasal administration is considered a non-invasive, easily operated, and effective method for cerebral drug delivery, which can easily cross the BBB and reach a high concentration in the brain [169]. Meanwhile, current animal studies of Alzheimer's disease [173] and Huntington's disease [85] have already presented the therapeutic potential of intranasally administered PACAP.

\section{Conclusion and future perspectives}

In conclusion, PACAP, which mainly acts through the PAC1 receptor, exerts neuroprotective effects against ischemic brain injury in vitro and in vivo. It bears potential as a new therapeutic strategy for stroke by targeting the pathophysiological processes of ionic homeostasis, excitotoxicity, cell edema, oxidative stress, neuroinflammation, and cell death. However, the role of PACAP in hemorrhagic stroke, and the specific underlying mechanisms need to be further explored. In addition, a better understanding of the upstream signaling components responsible for the upregulation of endogenous PACAP levels in the brain, and a further investigation of the role of VPAC1 and VPAC2 in PACAP-involved neuroprotection could help identify other effective therapeutic targets. Lastly, future welldesigned preclinical experiments are necessary to optimize therapeutic regimens of PACAP. This includes investigations to determine optimal windows of treatment, dosage, and routes of administration, as well determining whether there is any potential gender- or agerelated differences, which would facilitate the clinical translation of PACAP treatment in stroke patients.

\section{Acknowledgements}

This review was supported by grants from the National Institutes of Health (NS081740 and NS082184) of John H. Zhang, and the Key Program of Science and Technology Development of Zhejiang Province (2017C03021) and National Natural Science Foundation of China (81870916) of Jianmin Zhang.

\section{Conflict of Interest}

The authors report no conflict of interest concerning the findings specified in this paper.

\section{References}

[1] Hankey GJ (2017). Stroke. Lancet, 389: 641-654

[2] Sacco RL, Kasner SE, Broderick JP, Caplan LR, Connors JJ, Culebras A, et al. (2013). An updated definition of stroke for the 21st century: a statement for healthcare professionals from the American Heart Association/American Stroke Association. Stroke, 44: 2064-2089

[3] Chen S, Mei S, Luo Y, Wu H, Zhang J, Zhu J (2018). Gasdermin Family: a Promising Therapeutic Target for Stroke. Transl Stroke Res, 9: 555-563

[4] Fang Y, Gao S, Wang X, Cao Y, Lu J, Chen S, et al. (2020). Programmed Cell Deaths and Potential Crosstalk With Blood-Brain Barrier Dysfunction After Hemorrhagic Stroke. Frontiers in Cellular Neuroscience, 14

[5] Lo EH, Dalkara T, Moskowitz MA (2003). Mechanisms, challenges and opportunities in stroke. Nat Rev Neurosci, 4: 399-415

[6] Miyata A, Arimura A, Dahl RR, Minamino N, Uehara A, Jiang L, et al. (1989). Isolation of a novel 38 residuehypothalamic polypeptide which stimulates adenylate cyclase in pituitary cells. Biochem Biophys Res 
Commun, 164: 567-574

[7] Miyata A, Jiang L, Dahl RD, Kitada C, Kubo K, Fujino $\mathrm{M}$, et al. (1990). Isolation of a neuropeptide corresponding to the $\mathrm{N}$-terminal 27 residues of the pituitary adenylate cyclase activating polypeptide with 38 residues (PACAP38). Biochem Biophys Res Commun, 170: 643-648

[8] Vaudry D, Falluel-Morel A, Bourgault S, Basille M, Burel D, Wurtz O, et al. (2009). Pituitary adenylate cyclase-activating polypeptide and its receptors: 20 years after the discovery. Pharmacol Rev, 61: 283-357

[9] Harmar AJ, Fahrenkrug J, Gozes I, Laburthe M, May V, Pisegna JR, et al. (2012). Pharmacology and functions of receptors for vasoactive intestinal peptide and pituitary adenylate cyclase-activating polypeptide: IUPHAR review 1. Br J Pharmacol, 166: 4-17

[10] Rivnyak A, Kiss P, Tamas A, Balogh D, Reglodi D (2018). Review on PACAP-Induced Transcriptomic and Proteomic Changes in Neuronal Development and Repair. Int J Mol Sci, 19

[11] Ressler KJ, Mercer KB, Bradley B, Jovanovic T, Mahan A, Kerley K, et al. (2011). Post-traumatic stress disorder is associated with PACAP and the PAC1 receptor. Nature, 470: 492-497

[12] Tan YV, Waschek JA (2011). Targeting VIP and PACAP receptor signalling: new therapeutic strategies in multiple sclerosis. ASN Neuro, 3

[13] Kaiser EA, Russo AF (2013). CGRP and migraine: could PACAP play a role too? Neuropeptides, 47: 451461

[14] Nakamachi T, Ohtaki H, Seki T, Yofu S, Kagami N, Hashimoto H, et al. (2016). PACAP suppresses dry eye signs by stimulating tear secretion. Nat Commun, 7: 12034

[15] Uchida D, Arimura A, Somogyvari-Vigh A, Shioda S, Banks WA (1996). Prevention of ischemia-induced death of hippocampal neurons by pituitary adenylate cyclase activating polypeptide. Brain Res, 736: 280-286

[16] Ma BQ, Zhang M, Ba L (2015). Plasma pituitary adenylate cyclase-activating polypeptide concentrations and mortality after acute spontaneous basal ganglia hemorrhage. Clin Chim Acta, 439: 102106

[17] Jiang L, Wang WH, Dong XQ, Yu WH, Du Q, Yang DB, et al. (2016). The change of plasma pituitary adenylate cyclase-activating polypeptide levels after aneurysmal subarachnoid hemorrhage. Acta Neurol Scand, 134: 131-139

[18] Toth D, Tamas A, Reglodi D (2020). The Neuroprotective and Biomarker Potential of PACAP in Human Traumatic Brain Injury. Int J Mol Sci, 21

[19] Reglodi D, Vaczy A, Rubio-Beltran E, MaassenVanDenBrink A (2018). Protective effects of PACAP in ischemia. J Headache Pain, 19: 19

[20] Masuo Y, Ohtaki T, Masuda Y, Nagai Y, Suno M, Tsuda M, et al. (1991). Autoradiographic distribution of pituitary adenylate cyclase activating polypeptide (PACAP) binding sites in the rat brain. Neurosci Lett, 126: 103-106

[21] Masuo Y, Suzuki N, Matsumoto H, Tokito F,
Matsumoto Y, Tsuda M, et al. (1993). Regional distribution of pituitary adenylate cyclase activating polypeptide (PACAP) in the rat central nervous system as determined by sandwich-enzyme immunoassay. Brain Res, 602: 57-63

[22] Uddman R, Tajti J, Hou M, Sundler F, Edvinsson L (2002). Neuropeptide expression in the human trigeminal nucleus caudalis and in the cervical spinal cord C1 and C2. Cephalalgia, 22: 112-116

[23] Arimura A (1992). Receptors for pituitary adenylate cyclase-activating polypeptide: comparison with vasoactive intestinal peptide receptors. Trends Endocrinol Metab, 3: 288-294

[24] Hirabayashi T, Nakamachi T, Shioda S (2018). Discovery of PACAP and its receptors in the brain. $\mathrm{J}$ Headache Pain, 19: 28

[25] Hashimoto H, Nogi H, Mori K, Ohishi H, Shigemoto R, Yamamoto K, et al. (1996). Distribution of the mRNA for a pituitary adenylate cyclase-activating polypeptide receptor in the rat brain: an in situ hybridization study. J Comp Neurol, 371: 567-577

[26] Eftekhari S, Salvatore CA, Johansson S, Chen TB, Zeng Z, Edvinsson L (2015). Localization of CGRP, CGRP receptor, PACAP and glutamate in trigeminal ganglion. Relation to the blood-brain barrier. Brain Res, 1600: 93109

[27] Ishihara T, Shigemoto R, Mori K, Takahashi K, Nagata $\mathrm{S}$ (1992). Functional expression and tissue distribution of a novel receptor for vasoactive intestinal polypeptide. Neuron, 8: 811-819

[28] Usdin TB, Bonner TI, Mezey E (1994). Two receptors for vasoactive intestinal polypeptide with similar specificity and complementary distributions. Endocrinology, 135: 2662-2680

[29] Liao C, de Molliens MP, Schneebeli ST, Brewer M, Song G, Chatenet D, et al. (2019). Targeting the PAC1 Receptor for Neurological and Metabolic Disorders. Curr Top Med Chem, 19: 1399-1417

[30] Ster J, De Bock F, Guerineau NC, Janossy A, BarrereLemaire S, Bos JL, et al. (2007). Exchange protein activated by cAMP (Epac) mediates cAMP activation of p38 MAPK and modulation of $\mathrm{Ca} 2+$-dependent $\mathrm{K}+$ channels in cerebellar neurons. Proc Natl Acad Sci U S A, 104: 2519-2524

[31] May V, Buttolph TR, Girard BM, Clason TA, Parsons RL (2014). PACAP-induced ERK activation in HEK cells expressing PAC1 receptors involves both receptor internalization and PKC signaling. Am J Physiol Cell Physiol, 306: C1068-1079

[32] Yang K, Lei G, Jackson MF, Macdonald JF (2010). The involvement of PACAP/VIP system in the synaptic transmission in the hippocampus. J Mol Neurosci, 42: 319-326

[33] Mazzocchi G, Malendowicz LK, Neri G, Andreis PG, Ziolkowska A, Gottardo L, et al. (2002). Pituitary adenylate cyclase-activating polypeptide and PACAP receptor expression and function in the rat adrenal gland. Int J Mol Med, 9: 233-243

[34] Obara Y, Horgan AM, Stork PJ (2007). The requirement of Ras and Rap1 for the activation of ERKs by cAMP, 
PACAP, and $\mathrm{KCl}$ in cerebellar granule cells. J Neurochem, 101: 470-482

[35] Murthy KS, Zhang KM, Jin JG, Grider JR, Makhlouf GM (1993). VIP-mediated G protein-coupled Ca2+ influx activates a constitutive NOS in dispersed gastric muscle cells. Am J Physiol, 265: G660-671

[36] Barrie AP, Clohessy AM, Buensuceso CS, Rogers MV, Allen JM (1997). Pituitary adenylyl cyclase-activating peptide stimulates extracellular signal-regulated kinase 1 or 2 (ERK1/2) activity in a Ras-independent, mitogen-activated protein Kinase/ERK kinase 1 or 2dependent manner in PC12 cells. J Biol Chem, 272: 19666-19671

[37] Villalba M, Bockaert J, Journot L (1997). Pituitary adenylate cyclase-activating polypeptide (PACAP-38) protects cerebellar granule neurons from apoptosis by activating the mitogen-activated protein kinase (MAP kinase) pathway. J Neurosci, 17: 83-90

[38] Lelievre V, Pineau N, Du J, Wen CH, Nguyen T, Janet T, et al. (1998). Differential effects of peptide histidine isoleucine (PHI) and related peptides on stimulation and suppression of neuroblastoma cell proliferation. A novel VIP-independent action of PHI via MAP kinase. J Biol Chem, 273: 19685-19690

[39] Liu Y, Lu T, Zhang C, Xue Z, Xu J, Busuttil RW, et al. (2019). Pituitary Adenylate Cyclase-activating Polypeptides Prevent Hepatocyte Damage by Promoting Yes-associated Protein in Liver IschemiaReperfusion Injury. Transplantation, 103: 1639-1648

[40] Delgado M, Ganea D (1999). Vasoactive intestinal peptide and pituitary adenylate cyclase-activating polypeptide inhibit interleukin-12 transcription by regulating nuclear factor kappaB and Ets activation. $\mathrm{J}$ Biol Chem, 274: 31930-31940

[41] Delgado M (2003). Inhibition of interferon (IFN) gamma-induced Jak-STAT1 activation in microglia by vasoactive intestinal peptide: inhibitory effect on CD40, IFN-induced protein-10, and inducible nitric-oxide synthase expression. J Biol Chem, 278: 27620-27629

[42] Vlotides G, Zitzmann K, Hengge S, Engelhardt D, Stalla GK, Auernhammer CJ (2004). Expression of novel neurotrophin-1/B-cell stimulating factor-3 (NNT1/BSF-3) in murine pituitary folliculostellate $\mathrm{TtT} / \mathrm{GF}$ cells: pituitary adenylate cyclase-activating polypeptide and vasoactive intestinal peptide-induced stimulation of NNT-1/BSF-3 is mediated by protein kinase A, protein kinase $C$, and extracellular-signal-regulated kinase $1 / 2$ pathways. Endocrinology, 145: 716-727

[43] Shioda S, Ozawa H, Dohi K, Mizushima H, Matsumoto K, Nakajo S, et al. (1998). PACAP protects hippocampal neurons against apoptosis: involvement of JNK/SAPK signaling pathway. Ann N Y Acad Sci, 865: 111-117

[44] Dohi K, Mizushima H, Nakajo S, Ohtaki H, Matsunaga S, Aruga T, et al. (2002). Pituitary adenylate cyclaseactivating polypeptide (PACAP) prevents hippocampal neurons from apoptosis by inhibiting JNK/SAPK and p38 signal transduction pathways. Regul Pept, 109: 8388

[45] Castorina A, Scuderi S, D'Amico AG, Drago F, D'Agata
V (2014). PACAP and VIP increase the expression of myelin-related proteins in rat schwannoma cells: involvement of PAC1/VPAC2 receptor-mediated activation of PI3K/Akt signaling pathways. Exp Cell Res, 322: 108-121

[46] Waschek JA (2013). VIP and PACAP: neuropeptide modulators of CNS inflammation, injury, and repair. $\mathrm{Br}$ J Pharmacol, 169: 512-523

[47] Gabriel R, Postyeni E, Denes V (2019). Neuroprotective Potential of Pituitary Adenylate Cyclase Activating Polypeptide in Retinal Degenerations of Metabolic Origin. Front Neurosci, 13: 1031

[48] Rudecki AP, Gray SL (2016). PACAP in the Defense of Energy Homeostasis. Trends Endocrinol Metab, 27: 620-632

[49] Samal B, Gerdin MJ, Huddleston D, Hsu CM, Elkahloun AG, Stroth N, et al. (2007). Meta-analysis of microarray-derived data from PACAP-deficient adrenal gland in vivo and PACAP-treated chromaffin cells identifies distinct classes of PACAP-regulated genes. Peptides, 28: 1871-1882

[50] Lee M, Lelievre V, Zhao P, Torres M, Rodriguez W, Byun JY, et al. (2001). Pituitary adenylyl cyclaseactivating polypeptide stimulates DNA synthesis but delays maturation of oligodendrocyte progenitors. J Neurosci, 21: 3849-3859

[51] Falluel-Morel A, Vaudry D, Aubert N, Galas L, Benard M, Basille M, et al. (2005). Pituitary adenylate cyclaseactivating polypeptide prevents the effects of ceramides on migration, neurite outgrowth, and cytoskeleton remodeling. Proc Natl Acad Sci U S A, 102: 2637-2642

[52] Guirland C, Buck KB, Gibney JA, DiCicco-Bloom E, Zheng JQ (2003). Direct cAMP signaling through Gprotein-coupled receptors mediates growth cone attraction induced by pituitary adenylate cyclaseactivating polypeptide. J Neurosci, 23: 2274-2283

[53] Yuan ZL, Guan YJ, Wang L, Wei W, Kane AB, Chin YE (2004). Central role of the threonine residue within the $\mathrm{p}+1$ loop of receptor tyrosine kinase in STAT3 constitutive phosphorylation in metastatic cancer cells. Mol Cell Biol, 24: 9390-9400

[54] Kisseleva T, Bhattacharya S, Braunstein J, Schindler CW (2002). Signaling through the JAK/STAT pathway, recent advances and future challenges. Gene, 285: 1-24

[55] Vincze A, Reglodi D, Helyes Z, Hashimoto H, Shintani $\mathrm{N}$, Abraham H (2011). Role of endogenous pituitary adenylate cyclase activating polypeptide (PACAP) in myelination of the rodent brain: lessons from PACAPdeficient mice. Int J Dev Neurosci, 29: 923-935

[56] Nicot A, Lelievre V, Tam J, Waschek JA, DiCiccoBloom E (2002). Pituitary adenylate cyclase-activating polypeptide and sonic hedgehog interact to control cerebellar granule precursor cell proliferation. J Neurosci, 22: 9244-9254

[57] Vertongen P, Camby I, Darro F, Kiss R, Robberecht P (1996). VIP and pituitary adenylate cyclase activating polypeptide (PACAP) have an antiproliferative effect on the T98G human glioblastoma cell line through interaction with VIP2 receptor. Neuropeptides, 30: 491- 


\section{6}

[58] Hannibal J (2002). Pituitary adenylate cyclaseactivating peptide in the rat central nervous system: an immunohistochemical and in situ hybridization study. $\mathrm{J}$ Comp Neurol, 453: 389-417

[59] Hawke Z, Ivanov TR, Bechtold DA, Dhillon H, Lowell BB, Luckman SM (2009). PACAP neurons in the hypothalamic ventromedial nucleus are targets of central leptin signaling. J Neurosci, 29: 14828-14835

[60] Mounien L, Do Rego JC, Bizet P, Boutelet I, Gourcerol G, Fournier A, et al. (2009). Pituitary adenylate cyclaseactivating polypeptide inhibits food intake in mice through activation of the hypothalamic melanocortin system. Neuropsychopharmacology, 34: 424-435

[61] Matsuda K, Azuma M, Maruyama K, Shioda S (2013). Neuroendocrine control of feeding behavior and psychomotor activity by pituitary adenylate cyclaseactivating polypeptide (PACAP) in vertebrates. Obes Res Clin Pract, 7: e1-7

[62] Morton GJ, Cummings DE, Baskin DG, Barsh GS, Schwartz MW (2006). Central nervous system control of food intake and body weight. Nature, 443: 289-295

[63] Mounien L, Bizet P, Boutelet I, Gourcerol G, Fournier A, Vaudry H, et al. (2006). Pituitary adenylate cyclaseactivating polypeptide directly modulates the activity of proopiomelanocortin neurons in the rat arcuate nucleus. Neuroscience, 143: 155-163

[64] Inglott MA, Farnham MM, Pilowsky PM (2011). Intrathecal PACAP-38 causes prolonged widespread sympathoexcitation via a spinally mediated mechanism and increases in basal metabolic rate in anesthetized rat. Am J Physiol Heart Circ Physiol, 300: H2300-2307

[65] Resch JM, Boisvert JP, Hourigan AE, Mueller CR, Yi SS, Choi S (2011). Stimulation of the hypothalamic ventromedial nuclei by pituitary adenylate cyclaseactivating polypeptide induces hypophagia and thermogenesis. Am J Physiol Regul Integr Comp Physiol, 301: R1625-1634

[66] Resch JM, Maunze B, Gerhardt AK, Magnuson SK, Phillips KA, Choi S (2013). Intrahypothalamic pituitary adenylate cyclase-activating polypeptide regulates energy balance via site-specific actions on feeding and metabolism. Am J Physiol Endocrinol Metab, 305: E1452-1463

[67] Ciranna L, Costa L (2019). Pituitary Adenylate Cyclase-Activating Polypeptide Modulates Hippocampal Synaptic Transmission and Plasticity: New Therapeutic Suggestions for Fragile X Syndrome. Front Cell Neurosci, 13: 524

[68] Missig G, Roman CW, Vizzard MA, Braas KM, Hammack SE, May V (2014). Parabrachial nucleus $(\mathrm{PBn})$ pituitary adenylate cyclase activating polypeptide (PACAP) signaling in the amygdala: implication for the sensory and behavioral effects of pain. Neuropharmacology, 86: 38-48

[69] Missig G, Mei L, Vizzard MA, Braas KM, Waschek JA, Ressler KJ, et al. (2017). Parabrachial Pituitary Adenylate Cyclase-Activating Polypeptide Activation of Amygdala Endosomal Extracellular SignalRegulated Kinase Signaling Regulates the Emotional
Component of Pain. Biol Psychiatry, 81: 671-682

[70] Mustafa T (2013). Pituitary adenylate cyclaseactivating polypeptide (PACAP): a master regulator in central and peripheral stress responses. Adv Pharmacol, 68: $445-457$

[71] Rouwette T, Vanelderen P, Roubos EW, Kozicz T, Vissers K (2012). The amygdala, a relay station for switching on and off pain. Eur J Pain, 16: 782-792

[72] Gauriau C, Bernard JF (2002). Pain pathways and parabrachial circuits in the rat. Exp Physiol, 87: 251258

[73] Stevens JS, Almli LM, Fani N, Gutman DA, Bradley B, Norrholm SD, et al. (2014). PACAP receptor gene polymorphism impacts fear responses in the amygdala and hippocampus. Proc Natl Acad Sci U S A, 111: 31583163

[74] Atlasz T, Koszegi Z, Babai N, Tamas A, Reglodi D, Kovacs P, et al. (2006). Microiontophoretically applied PACAP blocks excitatory effects of kainic acid in vivo. Ann N Y Acad Sci, 1070: 143-148

[75] Manavalan S, Getachew B, Manaye KF, Khundmiri SJ, Csoka AB, McKinley R, et al. (2017). PACAP Protects Against Ethanol and Nicotine Toxicity in SH-SY5Y Cells: Implications for Drinking-Smoking Comorbidity. Neurotox Res, 32: 8-13

[76] Vaudry D, Pamantung TF, Basille M, Rousselle C, Fournier A, Vaudry H, et al. (2002). PACAP protects cerebellar granule neurons against oxidative stressinduced apoptosis. Eur J Neurosci, 15: 1451-1460

[77] Amato R, Biagioni M, Cammalleri M, Dal Monte M, Casini G (2016). VEGF as a Survival Factor in Ex Vivo Models of Early Diabetic Retinopathy. Invest Ophthalmol Vis Sci, 57: 3066-3076

[78] Gui LR, Zhou Y, Zhang BL, Li WB (2003). [Pituitary adenylate cyclase activating polypeptide protects neuro-2a cells from beta amyloid protein cytotoxicity by modulating intracellular calcium]. Sheng Li Xue Bao, 55: 42-46

[79] Sanchez A, Rao HV, Grammas P (2009). PACAP38 protects rat cortical neurons against the neurotoxicity evoked by sodium nitroprusside and thrombin. Regul Pept, 152: 33-40

[80] Kovesdi E, Tamas A, Reglodi D, Farkas O, Pal J, Toth $\mathrm{G}$, et al. (2008). Posttraumatic administration of pituitary adenylate cyclase activating polypeptide in central fluid percussion injury in rats. Neurotox Res, 13: 71-78

[81] Ohtaki H, Nakamachi T, Dohi K, Aizawa Y, Takaki A, Hodoyama K, et al. (2006). Pituitary adenylate cyclaseactivating polypeptide (PACAP) decreases ischemic neuronal cell death in association with IL-6. Proc Natl Acad Sci U S A, 103: 7488-7493

[82] Szabadfi K, Atlasz T, Kiss P, Danyadi B, Tamas A, Helyes Z, et al. (2012). Mice deficient in pituitary adenylate cyclase activating polypeptide (PACAP) are more susceptible to retinal ischemic injury in vivo. Neurotox Res, 21: 41-48

[83] Tsuchida M, Nakamachi T, Sugiyama K, Tsuchikawa D, Watanabe J, Hori M, et al. (2014). PACAP stimulates functional recovery after spinal cord injury through 
axonal regeneration. J Mol Neurosci, 54: 380-387

[84] Reglodi D, Lubics A, Tamas A, Szalontay L, Lengvari I (2004). Pituitary adenylate cyclase activating polypeptide protects dopaminergic neurons and improves behavioral deficits in a rat model of Parkinson's disease. Behav Brain Res, 151: 303-312

[85] Cabezas-Llobet N, Vidal-Sancho L, Masana M, Fournier A, Alberch J, Vaudry D, et al. (2018). Pituitary Adenylate Cyclase-Activating Polypeptide (PACAP) Enhances Hippocampal Synaptic Plasticity and Improves Memory Performance in Huntington's Disease. Mol Neurobiol, 55: 8263-8277

[86] Polanco MJ, Parodi S, Piol D, Stack C, Chivet M, Contestabile A, et al. (2016). Adenylyl cyclase activating polypeptide reduces phosphorylation and toxicity of the polyglutamine-expanded androgen receptor in spinobulbar muscular atrophy. Sci Transl Med, 8: 370ra181

[87] Shin CM, Chung YH, Kim MJ, Cha CI (2001). Spatial and temporal distribution of pituitary adenylate cyclase activating polypeptide in gerbil global cerebral ischemia. Neurosci Lett, 309: 53-56

[88] Matsumoto M, Nakamachi T, Watanabe J, Sugiyama K, Ohtaki H, Murai N, et al. (2016). Pituitary Adenylate Cyclase-Activating Polypeptide (PACAP) Is Involved in Adult Mouse Hippocampal Neurogenesis After Stroke. J Mol Neurosci, 59: 270-279

[89] Riek-Burchardt M, Kolodziej A, Henrich-Noack P, Reymann KG, Hollt V, Stumm R (2010). Differential regulation of CXCL12 and PACAP mRNA expression after focal and global ischemia. Neuropharmacology, 58: $199-207$

[90] Nakamachi T, Farkas J, Kagami N, Wada Y, Hori M, Tsuchikawa D, et al. (2013). Expression and distribution of pituitary adenylate cyclase-activating polypeptide receptor in reactive astrocytes induced by global brain ischemia in mice. Acta Neurochir Suppl, 118: 55-59

[91] Nakamachi T, Tsuchida M, Kagami N, Yofu S, Wada Y, Hori M, et al. (2012). IL-6 and PACAP receptor expression and localization after global brain ischemia in mice. J Mol Neurosci, 48: 518-525

[92] Miura A, Kambe Y, Inoue K, Tatsukawa H, Kurihara T, Griffin M, et al. (2013). Pituitary adenylate cyclaseactivating polypeptide type 1 receptor (PAC1) gene is suppressed by transglutaminase 2 activation. J Biol Chem, 288: 32720-32730

[93] Lin CH, Chiu L, Lee HT, Chiang CW, Liu SP, Hsu YH, et al. (2015). PACAP38/PAC1 signaling induces bone marrow-derived cells homing to ischemic brain. Stem Cells, 33: 1153-1172

[94] Gillardon F, Hata R, Hossmann KA(1998). Delayed upregulation of Zac1 and PACAP type I receptor after transient focal cerebral ischemia in mice. Brain Res Mol Brain Res, 61: 207-210

[95] Stumm R, Kolodziej A, Prinz V, Endres M, Wu DF, Hollt V (2007). Pituitary adenylate cyclase-activating polypeptide is up-regulated in cortical pyramidal cells after focal ischemia and protects neurons from mild hypoxic/ischemic damage. J Neurochem, 103: 1666-
1681

[96] Tamas A, Reglodi D, Szanto Z, Borsiczky B, Nemeth J, Lengvari I (2002). Comparative neuroprotective effects of preischemic PACAP and VIP administration in permanent occlusion of the middle cerebral artery in rats. Neuro Endocrinol Lett, 23: 249-254

[97] Chen Y, Samal B, Hamelink CR, Xiang CC, Chen Y, Chen M, et al. (2006). Neuroprotection by endogenous and exogenous PACAP following stroke. Regul Pept, 137: 4-19

[98] Reglodi D, Somogyvari-Vigh A, Vigh S, Maderdrut JL, Arimura A (2000). Neuroprotective effects of PACAP38 in a rat model of transient focal ischemia under various experimental conditions. Ann N Y Acad Sci, 921: 119-128

[99] Reglodi D, Somogyvari-Vigh A, Vigh S, Kozicz T, Arimura A (2000). Delayed systemic administration of PACAP38 is neuroprotective in transient middle cerebral artery occlusion in the rat. Stroke, 31: 14111417

[100] Hajji K, Mteyrek A, Sun J, Cassar M, Mezghani S, Leprince J, et al. (2019). Neuroprotective effects of PACAP against paraquat-induced oxidative stress in the Drosophila central nervous system. Hum Mol Genet, 28: 1905-1918

[101] Delgado M, Ganea D (2000). Vasoactive intestinal peptide and pituitary adenylate cyclase-activating polypeptide inhibit $\mathrm{T}$ cell-mediated cytotoxicity by inhibiting Fas ligand expression. J Immunol, 165: 114123

[102] Johnson GC, May V, Parsons RL, Hammack SE (2019). Parallel signaling pathways of pituitary adenylate cyclase activating polypeptide (PACAP) regulate several intrinsic ion channels. Ann N Y Acad Sci, 1455: $105-112$

[103] Kiss T, Balasubramanian P, Valcarcel-Ares MN, Tarantini S, Yabluchanskiy A, Csipo T, et al. (2019). Nicotinamide mononucleotide (NMN) treatment attenuates oxidative stress and rescues angiogenic capacity in aged cerebromicrovascular endothelial cells: a potential mechanism for the prevention of vascular cognitive impairment. Geroscience, 41: 619-630

[104] Stokum JA, Gerzanich V, Simard JM (2016). Molecular pathophysiology of cerebral edema. J Cereb Blood Flow Metab, 36: 513-538

[105] Lai TW, Zhang S, Wang YT (2014). Excitotoxicity and stroke: identifying novel targets for neuroprotection. Prog Neurobiol, 115: 157-188

[106] MacAulay N, Zeuthen T (2010). Water transport between CNS compartments: contributions of aquaporins and cotransporters. Neuroscience, 168: 941956

[107] Randall RD, Thayer SA (1992). Glutamate-induced calcium transient triggers delayed calcium overload and neurotoxicity in rat hippocampal neurons. J Neurosci, 12: $1882-1895$

[108] Gupte RP, Kadunganattil S, Shepherd AJ, Merrill R, Planer W, Bruchas MR, et al. (2016). Convergent phosphomodulation of the major neuronal dendritic potassium channel Kv4.2 by pituitary adenylate 
cyclase-activating polypeptide. Neuropharmacology, 101: 291-308

[109] Tompkins JD, Merriam LA, Girard BM, May V, Parsons RL (2015). Nickel suppresses the PACAPinduced increase in guinea pig cardiac neuron excitability. Am J Physiol Cell Physiol, 308: C857-866

[110] Merriam LA, Baran CN, Girard BM, Hardwick JC, May V, Parsons RL (2013). Pituitary adenylate cyclase 1 receptor internalization and endosomal signaling mediate the pituitary adenylate cyclase activating polypeptide-induced increase in guinea pig cardiac neuron excitability. J Neurosci, 33: 4614-4622

[111] Chen S, Wang J, Siegelbaum SA (2001). Properties of hyperpolarization-activated pacemaker current defined by coassembly of HCN1 and HCN2 subunits and basal modulation by cyclic nucleotide. J Gen Physiol, 117: 491-504

[112] Tompkins JD, Clason TA, Hardwick JC, Girard BM, Merriam LA, May V, et al. (2016). Activation of MEK/ERK signaling contributes to the PACAPinduced increase in guinea pig cardiac neuron excitability. Am J Physiol Cell Physiol, 311: C643C651

[113] Seo H, Lee K (2016). Epac2 contributes to PACAPinduced astrocytic differentiation through calcium ion influx in neural precursor cells. BMB Rep, 49: 128-133

[114] Dong Y, He C, Han X, Wang CH, Lu CL (2002). [Experimental study of pituitary adenylate cyclase activating polypeptide on relieving brain edema induced by ischemia in rats]. Zhongguo Ying Yong Sheng Li Xue Za Zhi, 18: 121-123

[115] Hafez S, Khan MB, Awad ME, Wagner JD, Hess DC (2019). Short-Term Acute Exercise Preconditioning Reduces Neurovascular Injury After Stroke Through Induced eNOS Activation. Transl Stroke Res,

[116] Nakamachi T, Ohtaki H, Yofu S, Dohi K, Watanabe J, Mori H, et al. (2010). Endogenous pituitary adenylate cyclase activating polypeptide is involved in suppression of edema in the ischemic brain. Acta Neurochir Suppl, 106: 43-46

[117] Warren JB, Larkin SW, Coughlan M, Kajekar R, Williams TJ (1992). Pituitary adenylate cyclase activating polypeptide is a potent vasodilator and oedema potentiator in rabbit skin in vivo. $\mathrm{Br} \mathrm{J}$ Pharmacol, 106: 331-334

[118] Banki E, Hajna Z, Kemeny A, Botz B, Nagy P, Bolcskei $\mathrm{K}$, et al. (2014). The selective PAC1 receptor agonist maxadilan inhibits neurogenic vasodilation and edema formation in the mouse skin. Neuropharmacology, 85: 538-547

[119] Ohtaki H, Dohi K, Yofu S, Nakamachi T, Kudo Y, Endo $\mathrm{S}$, et al. (2004). Effect of pituitary adenylate cyclaseactivating polypeptide 38 (PACAP38) on tissue oxygen content--treatment in central nervous system of mice. Regul Pept, 123: 61-67

[120] Bothwell SW, Janigro D, Patabendige A (2019). Cerebrospinal fluid dynamics and intracranial pressure elevation in neurological diseases. Fluids Barriers CNS, 16: 9

[121] Ironside N, Chen CJ, Ding D, Mayer SA, Connolly ES,
Jr. (2019). Perihematomal Edema After Spontaneous Intracerebral Hemorrhage. Stroke, 50: 1626-1633

[122] Kis B, Mezei Z, Dancso G, Pataricza J, Gecse A, Papp JG, et al. (1999). Effects of pituitary adenylate cyclaseactivating polypeptide on the cyclooxygenase pathway of rat platelets and on platelet aggregation. Prostaglandins Other Lipid Mediat, 58: 103-112

[123] Chamorro A, Dirnagl U, Urra X, Planas AM (2016). Neuroprotection in acute stroke: targeting excitotoxicity, oxidative and nitrosative stress, and inflammation. Lancet Neurol, 15: 869-881

[124] Morio H, Tatsuno I, Hirai A, Tamura Y, Saito Y (1996). Pituitary adenylate cyclase-activating polypeptide protects rat-cultured cortical neurons from glutamateinduced cytotoxicity. Brain Res, 741: 82-88

[125] Said SI, Dickman K, Dey RD, Bandyopadhyay A, De Stefanis P, Raza S, et al. (1998). Glutamate toxicity in the lung and neuronal cells: prevention or attenuation by VIP and PACAP. Ann N Y Acad Sci, 865: 226-237

[126] Tomimatsu N, Arakawa Y (2008). Survival-promoting activity of pituitary adenylate cyclase-activating polypeptide in the presence of phosphodiesterase inhibitors on rat motoneurons in culture: cAMP-protein kinase A-mediated survival. J Neurochem, 107: 628635

[127] Shintani N, Suetake S, Hashimoto H, Koga K, Kasai A, Kawaguchi C, et al. (2005). Neuroprotective action of endogenous PACAP in cultured rat cortical neurons. Regul Pept, 126: 123-128

[128] Onoue S, Endo K, Yajima T, Kashimoto K (2002). Pituitary adenylate cyclase-activating polypeptide and vasoactive intestinal peptide attenuate glutamateinduced nNOS activation and cytotoxicity. Regul Pept, 107: 43-47

[129] Kaneko Y, Tuazon JP, Ji X, Borlongan CV (2018). Pituitary Adenylate Cyclase Activating Polypeptide Elicits Neuroprotection Against Acute Ischemic Neuronal Cell Death Associated with NMDA Receptors. Cell Physiol Biochem, 51: 1982-1995

[130] Lenti L, Zimmermann A, Kis D, Olah O, Toth GK, Hegyi O, et al. (2009). PACAP and VIP differentially preserve neurovascular reactivity after global cerebral ischemia in newborn pigs. Brain Res, 1283: 50-57

[131] Lee SG, Su ZZ, Emdad L, Gupta P, Sarkar D, Borjabad A, et al. (2008). Mechanism of ceftriaxone induction of excitatory amino acid transporter-2 expression and glutamate uptake in primary human astrocytes. J Biol Chem, 283: 13116-13123

[132] Figiel M, Engele J (2000). Pituitary adenylate cyclaseactivating polypeptide (PACAP), a neuron-derived peptide regulating glial glutamate transport and metabolism. J Neurosci, 20: 3596-3605

[133] Ding WT, Yu P, Liu W, Zhou LQ, Guan L, Lin RS (2015). Buyang Huanwu decoction increases the expression of glutamate transporter-1 and glutamate synthetase in association with PACAP-38 following focal ischemia. Biomedical Reports, 3: 651-656

[134] Fumoto T, Naraoka M, Katagai T, Li Y, Shimamura N, Ohkuma H (2019). The Role of Oxidative Stress in Microvascular Disturbances after Experimental 
Subarachnoid Hemorrhage. Transl Stroke Res, 10: 684694

[135] Tabuchi A, Funaji K, Nakatsubo J, Fukuchi M, Tsuchiya T, Tsuda M (2003). Inactivation of aconitase during the apoptosis of mouse cerebellar granule neurons induced by a deprivation of membrane depolarization. J Neurosci Res, 71: 504-515

[136] Grumolato L, Elkahloun AG, Ghzili H, Alexandre D, Coulouarn C, Yon L, et al. (2003). Microarray and suppression subtractive hybridization analyses of gene expression in pheochromocytoma cells reveal pleiotropic effects of pituitary adenylate cyclaseactivating polypeptide on cell proliferation, survival, and adhesion. Endocrinology, 144: 2368-2379

[137] Ferencz A, Racz B, Tamas A, Reglodi D, Lubics A, Nemeth J, et al. (2009). Influence of PACAP on oxidative stress and tissue injury following small-bowel autotransplantation. J Mol Neurosci, 37: 168-176

[138] Yang S, Yang J, Yang Z, Chen P, Fraser A, Zhang W, et al. (2006). Pituitary adenylate cyclase-activating polypeptide (PACAP) 38 and PACAP4-6 are neuroprotective through inhibition of NADPH oxidase: potent regulators of microglia-mediated oxidative stress J Pharmacol Exp Ther, 319: 595-603

[139] Kong LY, Maderdrut JL, Jeohn GH, Hong JS (1999). Reduction of lipopolysaccharide-induced neurotoxicity in mixed cortical neuron/glia cultures by femtomolar concentrations of pituitary adenylate cyclase-activating polypeptide. Neuroscience, 91: 493-500

[140] Parsons JL, Dianova, II, Dianov GL (2004). APE1 is the major 3'-phosphoglycolate activity in human cell extracts. Nucleic Acids Res, 32: 3531-3536

[141] Stetler RA, Gao Y, Zukin RS, Vosler PS, Zhang L, Zhang F, et al. (2010). Apurinic/apyrimidinic endonuclease APE1 is required for PACAP-induced neuroprotection against global cerebral ischemia. Proc Natl Acad Sci U S A, 107: 3204-3209

[142] Gelderblom M, Leypoldt F, Steinbach K, Behrens D, Choe CU, Siler DA, et al. (2009). Temporal and spatial dynamics of cerebral immune cell accumulation in stroke. Stroke, 40: 1849-1857

[143] Chen GY, Nunez G (2010). Sterile inflammation: sensing and reacting to damage. Nat Rev Immunol, 10: 826-837

[144] Anrather J, Iadecola C (2016). Inflammation and Stroke: An Overview. Neurotherapeutics, 13: 661-670

[145] Denes V, Geck P, Mester A, Gabriel R (2019). Pituitary Adenylate Cyclase-Activating Polypeptide: 30 Years in Research Spotlight and 600 Million Years in Service. J Clin Med, 8

[146] Delgado M, Jonakait GM, Ganea D (2002). Vasoactive intestinal peptide and pituitary adenylate cyclaseactivating polypeptide inhibit chemokine production in activated microglia. Glia, 39: 148-161

[147] Alhadidi Q, Shah ZA (2018). Cofilin Mediates LPSInduced Microglial Cell Activation and Associated Neurotoxicity Through Activation of NF-kappaB and JAK-STAT Pathway. Mol Neurobiol, 55: 1676-1691

[148] Delgado M, Leceta J, Ganea D (2003). Vasoactive intestinal peptide and pituitary adenylate cyclase- activating polypeptide inhibit the production of inflammatory mediators by activated microglia. J Leukoc Biol, 73: 155-164

[149] Delgado M (2002). Vasoactive intestinal peptide and pituitary adenylate cyclase-activating polypeptide inhibit the MEKK1/MEK4/JNK signaling pathway in endotoxin-activated microglia. Biochem Biophys Res Commun, 293: 771-776

[150] Suk K, Park JH, Lee WH (2004). Neuropeptide PACAP inhibits hypoxic activation of brain microglia: a protective mechanism against microglial neurotoxicity in ischemia. Brain Res, 1026: 151-156

[151] Gottschall PE, Tatsuno I, Arimura A (1994). Regulation of interleukin-6 (IL-6) secretion in primary cultured rat astrocytes: synergism of interleukin-1 (IL-1) and pituitary adenylate cyclase activating polypeptide (PACAP). Brain Res, 637: 197-203

[152] Hori M, Nakamachi T, Rakwal R, Shibato J, Ogawa T, Aiuchi T, et al. (2012). Transcriptomics and proteomics analyses of the PACAP38 influenced ischemic brain in permanent middle cerebral artery occlusion model mice. J Neuroinflammation, 9: 256

[153] Hori M, Nakamachi T, Shibato J, Rakwal R, Tsuchida M, Shioda S, et al. (2014). PACAP38 differentially effects genes and CRMP2 protein expression in ischemic core and penumbra regions of permanent middle cerebral artery occlusion model mice brain. Int J Mol Sci, 15: 17014-17034

[154] Brifault C, Gras M, Liot D, May V, Vaudry D, Wurtz O (2015). Delayed pituitary adenylate cyclase-activating polypeptide delivery after brain stroke improves functional recovery by inducing $\mathrm{m} 2$ microglia/macrophage polarization. Stroke, 46: 520528

[155] Fang Y, Gao S, Wang X, Cao Y, Lu J, Chen S, et al. (2020). Programmed Cell Deaths and Potential Crosstalk With Blood-Brain Barrier Dysfunction After Hemorrhagic Stroke. Front Cell Neurosci, 14: 68

[156] Lazarovici P, Cohen G, Arien-Zakay H, Chen J, Zhang C, Chopp M, et al. (2012). Multimodal neuroprotection induced by PACAP38 in oxygen-glucose deprivation and middle cerebral artery occlusion stroke models. J Mol Neurosci, 48: 526-540

[157] Reglodi D, Fabian Z, Tamas A, Lubics A, Szeberenyi J, Alexy T, et al. (2004). Effects of PACAP on in vitro and in vivo neuronal cell death, platelet aggregation, and production of reactive oxygen radicals. Regul Pept, 123 : 51-59

[158] Jozwiak-Bebenista M, Kowalczyk E, Nowak JZ (2015). The cyclic AMP effects and neuroprotective activities of PACAP and VIP in cultured astrocytes and neurons exposed to oxygen-glucose deprivation. Pharmacol Rep, 67: $332-338$

[159] Rasbach E, Splitthoff P, Bonaterra GA, Schwarz A, Mey L, Schwarzbach H, et al. (2019). PACAP deficiency aggravates atherosclerosis in ApoE deficient mice. Immunobiology, 224: 124-132

[160] Fang Y, Chen S, Reis C, Zhang J (2018). The Role of Autophagy in Subarachnoid Hemorrhage: An Update. Curr Neuropharmacol, 16: 1255-1266 
[161] D'Amico AG, Maugeri G, Saccone S, Federico C, Cavallaro S, Reglodi D, et al. (2020). PACAP Modulates the Autophagy Process in an In Vitro Model of Amyotrophic Lateral Sclerosis. Int J Mol Sci, 21

[162] Chen XY, Du YF, Chen L (2018). Neuropeptides Exert Neuroprotective Effects in Alzheimer's Disease. Front Mol Neurosci, 11: 493

[163] Xue Z, Zhang Y, Liu Y, Zhang C, Shen XD, Gao F, et al. (2020). PACAP neuropeptide promotes Hepatocellular Protection via CREB-KLF4 dependent autophagy in mouse liver Ischemia Reperfusion Injury. Theranostics, 10: 4453-4465

[164] Zhang C, Jiang M, Wang WQ, Zhao SJ, Yin YX, Mi QJ, et al. (2019). Selective mGluR1 Negative Allosteric Modulator Reduces Blood-Brain Barrier Permeability and Cerebral Edema After Experimental Subarachnoid Hemorrhage. Transl Stroke Res,

[165] Steliga A, Kowianski P, Czuba E, Waskow M, Morys J, Lietzau G (2019). Neurovascular Unit as a Source of Ischemic Stroke Biomarkers-Limitations of Experimental Studies and Perspectives for Clinical Application. Transl Stroke Res,

[166] Wilhelm I, Fazakas C, Tamas A, Toth G, Reglodi D, Krizbai IA (2014). PACAP enhances barrier properties of cerebral microvessels. J Mol Neurosci, 54: 469-476

[167] Knutsson M, Edvinsson L (2002). Distribution of mRNA for VIP and PACAP receptors in human cerebral arteries and cranial ganglia. Neuroreport, 13: 507-509

[168] Banki E, Sosnowska D, Tucsek Z, Gautam T, Toth P, Tarantini S, et al. (2015). Age-related decline of autocrine pituitary adenylate cyclase-activating polypeptide impairs angiogenic capacity of rat cerebromicrovascular endothelial cells. J Gerontol A Biol Sci Med Sci, 70: 665-674

[169] Reglodi D, Atlasz T, Jungling A, Szabo E, Kovari P, Manavalan S, et al. (2018). Alternative Routes of Administration of the Neuroprotective Pituitary Adenylate Cyclase Activating Polypeptide. Curr Pharm Des, 24: 3892-3904

[170] Amin FM, Schytz HW (2018). Transport of the pituitary adenylate cyclase-activating polypeptide across the blood-brain barrier: implications for migraine. $\mathrm{J}$ Headache Pain, 19: 35

[171] Reglodi D, Tamas A, Somogyvari-Vigh A, Szanto Z, Kertes E, Lenard L, et al. (2002). Effects of pretreatment with PACAP on the infarct size and functional outcome in rat permanent focal cerebral ischemia. Peptides, 23: 2227-2234

[172] Somogyvari-Vigh A, Svoboda-Teet J, Vigh S, Arimura A (1998). Is an intravenous bolus injection required prior to initiating slow intravenous infusion of PACAP38 for prevention of neuronal death induced by global ischemia? The possible presence of a binding protein for PACAP38 in blood. Ann N Y Acad Sci, 865: 595-600

[173] Rat D, Schmitt U, Tippmann F, Dewachter I, Theunis C, Wieczerzak E, et al. (2011). Neuropeptide pituitary adenylate cyclase-activating polypeptide (PACAP) slows down Alzheimer's disease-like pathology in amyloid precursor protein-transgenic mice. FASEB J, 25: $3208-3218$ 